\title{
PENGARUH KOMPETENSI PEDAGOGIK GURU, PENDIDIKAN KARAKTER, DAN FASILITAS BELAJAR TERHADAP PRESTASI BELAJAR IPS DI SMP NASIONAL MALANG
}

\author{
Mado Lipat Goreti Maria \\ e-mail:maria@gmail.com \\ Endah Andayani \\ e-mail: endahandayani@unikama.ac.id \\ Naim \\ e-mail: kornanaim68@yahoo.com
}

(Program Studi Pendidikan Ekonomi, Fakultas Ekonomika dan Bisnis, Universitas Kanjuruhan, Malang)

\begin{abstract}
This study aims to determine whether there is influence between teacher pedagogical competence, character education and learning facilities on social studies learning achievement in VIII grade of Malang National Junior High School and to find out how much influence between teacher pedagogical competence, character education and learning facilities on social studies learning achievement together with students of class VIII of Malang National Middle School. Total population of 116 samples used 47 students proportional random sampling. Data collection was conducted using a questionnaire and documentation method. This type of research uses a quantitative research approach. The method of multiple linear regression research. Hypothesis testing using $t$ test and $F$ test. The results of this study indicate that there is a significant influence of teacher pedagogical competence variables on social studies learning achievement of $6.522 \%$. The significant influence of character education on social studies learning achievement is $43.65 \%$. The significant influence of learning facilities on social studies learning achievement is $40.21 \%$. Based on the results of the processed data test it can be seen that the variable pedagogical competence of teachers, character education and learning facilities has a simultaneous or joint effect on social studies learning achievement of $65,3 \%$.
\end{abstract}

Keywords : Teacher Pedagogical Competencies, Character Education, Learning Facilities, Social Studies Learning Achievement

\begin{abstract}
Abstrak: Penelitian ini bertujuan untuk mengetahui ada tidaknya pengaruh antara kopetensi pedagogik guru, pendidikan karakter dan fasilitas belajar terhadap prestasi belajar IPS kelas VIII SMP Nasional Malang dan untuk mengetahui seberapa besar pengaruh antara kompetensi pedagogik guru, pendidikan karakter dan fasilitas belajar terhadap prestasi belajar IPS secara bersama- sama siswa kelas VIII SMP Nasional Malang. Jumlah populasi 116 sampel yang digunakan 47 siswa propotional random sampling. Pengumpulan data dilakukan dengan metode angket dan dokumentasi. Jenis penelitian menggunakan pendekatan penelitian kuantitatif. Metode penelitian regresi linier berganda. Pengujian hipotesis menggunakan uji $t$ dan uji F. Hasil penelitian ini menunjukan adanya pengaruh yang signifikan variabel kompetensi pedagogik guru terhadap prestasi belajar IPS sebesar 6,522\%. Adanya pengaruh signifikan pendidikan karakter terhadap prestasi belajar IPS sebesar 43,65\%. Adanya pengaruh signifikan fasilitas belajar terhadap prestasi belajar IPS sebesar 40,21\%. Berdasarkan pada hasil uji data yang diolah dapat diketahui bahwa variabel kompetensi pedagogik guru, pendidikan karakter dan fasilitas belajar memiliki pengaruh secara simultan atau bersama-sama terhadap prestasi belajar IPS sebesar $65,3 \%$.
\end{abstract}

Kata kunci : Kompetensi Pedagogik Guru, Pendidikan Karakter, Fasilitas Belajar, Prestasi Belajar IPS 


\section{PENDAHULUAN}

Prestasi belajar siswa kelas VIII SMP Nasional Malang dari pengamatan yang saya teliti masih menurun. Hal ini dapat dilihat dari keaktifan dan perhatian siswa pada saat belajar di kelas masih kurang antusias atau kurang tertarik pada saat menerima materi pembelajaran yang diberikan oleh guru dan hal ini juga dapat di karenakan kurangnya kompetensi guru pada saat mengajarserta fasilitas belajar di sekolah kurang mendukung sehinga menyebabkan prestasi belajar siswa menurun.

Suatu lembaga pendidikan formal, dalam hal ini sekolah SMP Nasional Malang dapat dikatakan bagus atau baik bilah lembaga tersebut memiliki Kepalah sekolah dan tenaga pendidik yang berkualitas dan mampu melaksanakan kegiatan pembelajaran yang baik, sehingga tercapai tujuan yang diinginkan baik tujuan dari lembaga maupun tujuan siswa. Guru merupakan salah satu faktor penentu berhasil tidaknya suatu pembelajaran. Keberhasilan penyelenggara pembelajaran sangat ditentukan oleh sejauh mana kesiapan guru dalam mempersiapkan perserta didiknya melalui kegiatan pembelajaran. Apabilah guru memiliki kesiapan yang kurang, guru tersebut tidak dapat memberikan performa yang optimal dan cendrum kurang bagus sehingga persepsi siswa terhadap guru tersebut biasanya memandang negatif dan memandang rendah. Oleh karena itu Kompetensi guru dinilai sangat berpengaruh terhadap prestasi belajar mata pelajaran IPS.

Wahyudi (2012) Kompetensi pedagogik yaitu kemampuan seseorang guru dalam mengelola proses pembelajaran peserta didik. Selain itu kemampuan pedagogik juga ditunjukan dalam membantu membimbing dan memimpin peserta didik. Jika seorang guru memiliki kompetensi pedagogik guru, guru tersebut bisa mengelolah pembelajaran peserta didik yang meliputi pemahaman terhadap peserta didik, perancangan dan pelaksanaan pembelajaran, evaluasi hasil belajar dan pengembangan peserta didik untuk mengaktualisasikan berbagai potensi yang dimilikinya.

Pendidikan karakter bukan sekedar mengajarkan mana yang benar dan mana yang salah akan tetapi lebih dari itu. Pendidikan karakter menanamkan kebiasaan tentang hal mana yang baik sehingga peserta didik menjadi paham tentang mana yang benar dan mana yang salah., mampu merasakan nilai yang baik dan perilaku yang baik. Pendidikan karakter menekankan pada kebiasaan yang terus menerus dipraktekan dan dilakukan. Menurut Aunillah (2011) Pendidikan karakter merupakan sebuah sistem yang menanamkan nilai-nilai karakter pada peserta didik yang mengandung komponen pengetahuan, kesadaran individu, tekad, serta adanya kemauan dan tindakan untuk melaksanakan nilai-nilai baik terhadap Tuhan Yang maha Esa, diri sendiri, sesama manusia, lingkungan maupun bangsa sehingga terwujud insan kamil.

Pendidikan karakter yang ada di SMP Nasional Malang sangatlah kurang. Terbukti pada saat peneliti magang III, pada saat gurunya tidak masukkelas ataupun terlambat masuk, siswa tidak ada inisiatif untuk belajar sendiri. Siswa malah keluar masuk kelas,ribut di kelas dan menggangu teman kelas lain yang lagi mengikuti KBM serta kurang hormatnya kepada bapak/ibu guru disekolah. Fasilitas belajar merupakan salah satu faktor eksternal untuk mendukung prestasi belajar siswa disekolah. Arikunto Suharsimi (2010) "fasilitas belajar sangat penting dalam proses pembelajaran untuk mendukung kegiatan pengajaran dan juga dapat menimbulkan minat dan perhatian dari siswa untuk mepermudah penyampaian materi pembelajaran". Demikian halnya dengan SMP Nasional Malang yang senantiasa mendorong siswanya untuk selalu berprestasi dengan menyediakan berbagai fasilitas belajar yang memadai dengan pengelolaan yang baik guna menunjang kegiatan 
belajar mengajar. Kegiatan belajar mengajar memerlukan adanya fasilitas, agar kegiatan tersebut berjalan dengan lancar dan teratur. Fasilitas dalam kegiatan belajar mengajar di SMP Nasional Malang antara lain berupa ruang kelas, perpustakaan, laboratorium, media penyampaian materi dan lain sebagainaya

\section{TINJAUAN PUSTAKA}

Prestasi belajar adalah hasil yang diperoleh dalam proses pembelajaran, sebagai bukti keberhasilannya dalam aktivitas dalam belajar yang meliputi ranah kognitif ,afektif dan psikomotor. Dalam penelitian ini lebih terfokus pada aspek kognitif. Aspek kogniktif merupakan aspek yang paling dominan dinilai oleh guru-guru disekolah karena berkaitan dengan kemampuan siswa dalam menguasai isi bahan pelajaran. Hasil dari keberhasilan prestasi tersebut dinyatakan dalam bentuk nilai atau rapor setelah diadakan evaluasi. Prestasi belajar untuk mengetahui pencapain siswa terhadap materi pelajaran yang telah dipelajari selama berlangsungnya proses pembelajaran.

Departemen Pendidikan Nasional (2014), prestasi belajar adalah hasil dari suatu kegiatan yang telah dikerjakan, diciptakan baik secara individual maupun kelompok. Prestasi tidak akan pernah dihasilkan selama seseorang tidak melakukan suatu kegiatan. Dalam kenyataan untuk mendapatkan prestasi tidak semudah yang dibayangan, tetapi penuh perjuangan dengan berbagai tantangan yang harus dihadapi untuk mencapainya. Rusman (2013:54) menyatakan bahwa kompetensi pedagogik meliputi pemahaman terhadap peserta didik, perencanaan dan pelaksanaan kegiatan pembelajaran, evaluasi hasil belajar dan pengembangan peserta didik untuk mengaktualisasikan berbagai potensi yang dimiliki peserta didik. Berkenaan dengan pelaksanaan kurikulum, seorang guru harus mampu mengembangkan kurikulum berdasarkan tingkat satuan pendidikannya masing-masing dan disesuaikan dengan kebutuhan lokal. Di samping itu guru harus mampu menerapkan teknologi informasi dan komunikasi dalam pembelajarannya yaitu menggunakan berbagai media dan sumber belajar yang relevan dan menarik perhatian peserta didik sehingga tujuan pembelajaran tercapai secara optimal.

Suyanto dan Asep Jihad (2013) dalam bukunya menjadi guru profesional kompetensi pedagogik yang harus dikuasai guru meliputi pemahaman guru terhadap siswa, perancangan dan pelaksanaan pembelajaran, evaluasi hasil belajar, dan pengembangan siswa untuk mengaktualisasikan berbagai potensi yang dimilikinya. Secara rinci, tiap sub kompetensi dijabarkan menjadi indikator esensial sebagai berikut:

1. Memahami siswa secara mendalam, dengan indikator esensial: memahami siswa dengan memanfaatkan prinsip -prinsip perkembangan kognitif; memahami siswa dengan memanfaatkan prinsip-prinsip kepribadian dan mengidentifikasi bekal ajar awal siswa.

2. Merancang pembelajaran, termasuk memahami landasan pendidikan untuk kepentingan pembelajaran, dengan indikator esensial: memahami landasan kependidikan; menerapkan teori belajar dan pembelajaran,menentukan strategi pembelajaran berdasarkan karakteristik siswa, menetapkan kompetensi yang ingin dicapai, dan materi ajar; serta menyusun rancangan pembelajaran berdasarkan strategi yang dipilih.

3. Melaksanakan pembelajaran, dengan indikator esensial: menata latar pembelajaran dan melaksanakan pembelajaran yang kondusif. 
4. Merancang dan melaksanakan evaluasi pembelajaran, dengan indikator sensial: merancang dan melaksanakan evaluasi proses dan hasil belajar secara berkesinambungan dengan berbagai metode, menganalisis hasil evaluasi proses dan hasil belajar untuk menentukan tingkat ketuntasan belajar; dan memanfaatkan hasil penilaian pembelajaran untuk perbaikan kualitas program pembelajaran secara umum.

5. Mengembangkan siswa untuk mengaktualisasikan berbagai potensinya dengan indikator esensial; memfasilitasi siswa untuk pengembangan berbagai potensi akademik; dan memfasilitasi siswa untuk mengembangkan berbagai potensi non akademik.

Pendidikan karakter adalah segala sesuatu yang dilakukan guru, yang mampu mempengaruhi karakter peserta didik. Guru membantu membentuk watak peserta didik. Hal ini mencakup keteladanan bagaimana perilaku guru, cara guru berbicara atau menyampaikan materi, bagaimana guru bertoleransi, dan berbagai hal terkait lainnya. Pendidikan karakter di sekolah, semua komponen (pemangku pendidikan) harus dilibatkan termasuk komponen-komponen pendidikan itu sendiri, yaitu isi kurikulum, proses pembelajaran dan penilaian, penanganan atau pengolahan mata pelajaran, pengolahan sekolah, pelaksanaan aktivitas, pemberdayaan sarana prasarana. Thomas Lickona (2011) mendefinisikan seseorang yang berkarakter sebagai sifat alami seorang dalam merespon situasi secara bermoral, yang dimanifestasikan dalam tindakan nyata melalui tingkah laku yang baik, jujur, bertanggungjawab, menghormati orang lain dan karakter mulia lainnya.

Fasilitas dapat diartikan sebagai salah satu yang dapat memudahkan dan memperlancar pelaksanaan segala usaha. Adapun yang dimaksudkan dengan fasilitas belajar adalah semua kebutuhan yang diperlikan oleh peserta didik dalam rangka untuk memudahkan, melancarkan dan menunjang dalam kegiatan belajar disekolah. Supaya lebih efektif dan efisien yang nantinya peserta didik dapat belajar dengan maksimal dan hasil belajar yang memuaskan. Zakiah (2008), "Fasilitas adalah segala sesuatu yang dapat mempermudah upaya dan memperlancar kerja dalam rangka mencapai suatu tujuan".

\section{METODE}

Penelitian ini menggunakan pendekatan kuantitatif, yang memiliki sejumlah ciri-ciri yang membedakannya dengan penelitian jenis lainnya. Sumanto (2008:12) menjelaskan "penelitian kuantitatif merupakan jenis penelitian yang menekankan pada aspek pengukuran yang secara obyektif terhadap fenomena sosial, semua informasi atau data yang diperoleh diwujudkan dengan angka dan analisis yang digunakan adalah analisis statistik". Jenis penelitian ini termasuk dalam penelitian ex-post-facto, karena peneliti berhubungan dengan variabel yang telah terjadi dan mereka tidak perlu memberikan perlakuan terhadap variabel yang diteliti. Penelitian ini ditujukan untuk mengetahui pengaruh kompetensi guru, pendidikan karakter dan fasilitas belajar terhadap prestasi belajar.

Populasi dalam penelitian ini adalah seluruh siswa kelas VIII di SMP Nasional Malang. Populasi tersebut memiliki karakteristik antara lain: 1) Seluruhnya merupakan siswa kelas VIII di SMP Nasional Malang, 2) Sama-sama mendapatkan pengajaran IPS. Diketahui bahwa jumlah populasi penelitian sebanyak 116 siswa, maka populasi penelitian ini dapat diambil sampelnya. Yang mana dari masing-masing kelas diambil 30\% untuk dijadikan sampel yang akan mewakili populasi. Adapun jumlah sampelnya sebesar 32 siswa. Teknik pengumpulan data merupakan cara yang 
digunakan dalam pengumpulan data penelitian, untuk memperoleh data yang diperlukan dalam penelitian ini, peneliti menggunakan dua teknik pengumpulan data yaitu Kuesioner (angket) dan Dokumentasi.

Peneliti menggunakan alat analisis regresi linear berganda yang fungsinya adalah untuk mengetahui pengaruh secara bersama-sama (simultan) maupun sendiri-sendiri (parsial) antara variabel bebas yang teridiri dari kompetensi pedagogik guru (X1) pendidikan karakter (X2), dan Fasilitas belajar (X3) dengan variabel terikat prestasi belajar (Y).

Sebelum dilakukan analisis regresi linear berganda, maka dilakukan uji prasyarat analiis regresi yaitu: Uji Normalitas, Uji Multikolinearitas, Uji Heteroskedastisitas dan Uji Autokorelasi. Kemudian dilanjutkan dengan uji t (parsial) dan uji F (simultan).

\section{PEMBAHASAN}

Pengaruh kompetensi pedagogik guru, pendidikan karakter dan fasilitas sekolah terhadap prestasi belajar siswa.

Secara silmultan atau secara bersama-sama menunjukkan terdapat pengaruh yang signifikan antara kompetensi guru (X1), pendidikan karakter (X2) dan fasilitas belajar (X3) Terhadap prestasi belajar siswa di kelas VIII SMP Nasional Malang. Hal ini dibuktikan dengan F hitung sebesar 65,332. Secara parsial hasil penelitian ini sesuai dengan penelitian yang dilakukan oleh Ridaul Inayah (2011) yang berjudul "Pengaruh kompetensi guru, motivasi belajar dan fasilitas belajar terhadap prestasi belajar mata pelajaran Ekonomi pada siswa kelas XI IPS SMA Negeri 1 Lasem.". penelitian tersebut menunjukkan terdapat pengaruh kompetensi guru (X1), Terhadap prestasi belajar (Y) pada siswa kelas XI IPS SMA Negeri 1 Lasem. Dari hasil penelitian di atas dan didukung oleh beberapa penelitian terdahulu maka peneliti mempunyai keyakinan bahwa secara bersama-sama antara sumber kompetensi pedagogik guru (X1), pendidikan karakter (X2) dan fasilitas belajar (X3) memberikan pengaruh yang besar dengan bukti dari hasil penelitian sebesar 65,332\%. Sedangkan sisanya sebesar $34,668 \%$ ditentukan oleh variabel/faktor lain yang tidak dibahas dalam penelitian ini sseperti intelejensi, perhatian orang tua, pendapatan orang tua, bakat dan lain sebagainya.

\section{Pengaruh kompetensi pedagogik guru terhadap prestasi belajar IPS}

Berdasarkan hasil analisis data yang dilakukan secara parsial menunjukkan bahwa terdapat pengaruh antara kompetensi pedagogik guru (X1) terhadap prestasi belajar (Y). Dapat disimpulkan bahwa kompetensi pedagogik guru berpengaruh secara positif terhadap prestasi belajar yaitu se besar $65,22 \%$. Artinya semakin semakin berkompeten seorang guru maka pretasi belajar siswa SMP Nasional semakin baik atau meningkat pula. Hasil penilitian ini sama dengan yang dilakukan oleh Nur Aziza (2015) Pengaruh kompetensi pedagogik guru dan fasilitas belajar terhadap prestasi belajar pengantar ekonomi dan bisnis siswa kelas X program keahlian akuntansi SMKN 1 Klaten tahun ajaran 2014/2015. Dilihat dari hasil temuan dan didukung oleh penelitian terdahulu, peneliti mempunyai keyakinan bahwa pengaruh kompetensi guru tergolong besar karena mencapai 65,22\%, semoga dengan hasil temuan ini dapat memberikan informasi yang penting bagi pihak sekolah sehingga pihak sekolah mengambil kebijakan-kebijakan yang mampu mengkonsistensikan atau bahkan meningkatkan kompetensi guru dan berimplikasi terhadap prestasi belajar siswa.

Pengaruh pendidikan karakter siswa terhadap prestasi belajar IPS 
Berdasarkan hasil analisis secara statistik pendidikan karakter siswa (X2) berpengaruh secara signifikan terhadap variabel prestasi belajar siswa (Y), Dapat disimpulkan bahwa pendidikan karakter berpengaruh secara positif terhadap prestasi belajar siswa yaitu sebesar 43,65\%. Artinya semakin baik atau semakin bagus karakter siswa dilingkungan masyarakat maupun di sekolah maka prestasi belajar siswa semakin baik pula. Hasil penelitian ini sama dengan yang dilakukan oleh Debi Firmansya dalam penelitiannya yang berjudul “Debi Firmansya (2012) Pengaruh pendidikan karakter, lingkungan sekolah dan motivasi terhadap hasil belajar siswa kelas X Tata Niaga di SMK-E Adi Karya Kabupaten Pesisir Selatan.". Sofan Amri (2011:167) menjelaskan bahwa karakter merupakan cara berpikir dan berperilaku yang menjadi khas tiap individu untuk hidup dan bekerjasama, baik dalam lingkup keluarga, masyarakat, bangsa dan Negara. Seorang yang berkarakter baik adalah individu yang bisa membuat keputusan dan bertanggungjawab. Lebih lanjut Furqon Hidayatullah (2010:13) menjelaskan bahwa karakter merupakan kualitas atau kekuatan mental atau moral, akhlak atau budi pekerti individu yang merupakan kepribadian khusus yang menjadi pendorong dan penggerak, serta yang membedakan dengan individu lain. Karakter juga bisa dikatakan sebagai perilaku seseorang yang didasarkan pada nilai-nilai sesuai norma-norma yang berlaku. Karakter yang diperlihatkan melalui perkataan, perbuatan dan tingkah laku bisa baik dan bisa tidak baik berdasarkan penilaian lingkungannya.dilakukan dalam lingkungan sosial dan budaya yang bersangkutan.

\section{Pengaruh fasilitas belajar Terhadap prestasi belajar IPS}

Secara parsial hasil penelitian menunjukkan bahwa terdapat pengaruh yang positif dan signifikan antara fasilitas belajar (X3) terhadap prestasi belajar siswa (Y) yaitu sebesar 40,21\%. Hasil penelitian ini sama dengan yang dilakukan oleh Beni Setyawan (2014) Pengaruh fasilitas belajar dan motivasi belajar terhadap prestasi belajar prodi Ekonomi BKK Administrasi Perkantoran, FKIP Universitas Sebelas Maret. Berdasarkan hasil penelitian menunjukan bahwa variabel X1 fasilitas belajar, X2 motivasi belajar terhadap prestasi belajar prodi Ekonomi BKK Administrasi Perkantoran, FKIP Universitas Sebelas Maret sebesar 33,5\%, dan disimpulkan bahwa fasilitas belajar, motivasi belajar memiliki pengaruh terhadap prestasi belajar yang cukup besar.

Suharisimi Arikunto (2010) mengatakan bahwa "fasilitas dapat diartikan sebagai salah satu yang dapat memudahkan dan memperlancar pelaksanaan segala usaha". Adapun yang dimaksudkan dengan fasilitas belajar adalah semua kebutuhan yang diperlikan oleh peserta didik dalam rangka untuk memudahkan, melancarkan dan menunjang dalam kegiatan belajar disekolah. Supaya lebih efektif dan efisien yang nantinya peserta didik dapat belajar dengan maksimal dan hasil belajar yang memuaskan.

\section{KESIMPULAN}

Berdasarkan hasil penelitian yang telah dilakukan dan dianalisis maka ada beberapa hal yang perlu disimpulkan antara lain: 1)Terdapat pengaruh yang signifikan antara kompetensi pedagogik guru, pendidikan karakter dan fasilitas belajar terhadap prestasi belajar IPS siswa kelas VIII di SMP Nasional Malang, 2) Terdapat pengaruh yang signifikan kompetensi pedagogik guru (X1) terhadap prestasi belajar IPS siswa kelas VIII di SMP Nasional Malang, 3) Terdapat pengaruh yang signifikan antara pendidikan karakter (X2) terhadap prestasi belajar IPS siswa kelas VIII di SMP Nasional 
Malang, 4) Terdapat pengaruh yang signifikan antara fasilitas belajar (X3) terhadap prestasi belajar IPS siswa kelas VIII di SMP Nasional Malang.

\section{DAFTAR PUSTAKA}

Arikunto, Suharsimi (2009). “Dasar-Dasar Evaluasi Pendidikan". Jakarta : Bumi Aksara.

Aunillah (2011). Panduan Menerapkan Pendidikan Karakter di Sekolah. Jakarta: Erlangga.

Beni Setyawan (2014). "Pengaruh Fasilitas Belajar dan Motivasi Belajar terhadap Prestasi Belajar prodi

Ekonomi BKK Adiministrasi Perkantoran, FKIP Universitas Sebelas Maret". Jurnal Adminstrasi Bisnis (JAB).

Debi Firmansya (2012). "Pengaruh Pendidikan Karakter, Lingkungan Sekolah dan Motivasi terhadap Hasil Belajar Siswa kelas X Tata Niaga di SMK-E Adi Karya Kabupaten Pesisir Selatan". Jurnal Fakultas Ekonomi Universitas Indonesia.

Departemen Pendidikan Nasional (2014). “Kamus Besar Bahasa Indonesia Cetakan ke Delapan Belas Edisi IV". Jakarta : Gremedia Pustaka Utama

Hidayatullah, Furqon (2010). Pendidikan Karakter: Membangun Peradaban Bangsa. Surakarta: UNS Press\&Yuma Pustaka.

Nur Aziza (2015). "Pengaruh kompetensi pedagogik guru dan fasilitas belajar terhadap prestasi belajar pengantar ekonomi dan bisnis siswa kelas X program keahlian akuntansi SMKN 1 Klaten tahun ajaran 2014/2015". Jurnal Pendidikan Insan Mandiri.

RusmaN (2010). “Model-Model Pembelajaan”. Jakarta : Rajawali Pers.

Ridaul Inayah (2011). "Pengaruh Kompetensi Guru, Motivasi Belajar Siswa dan fasilitas Belajar terhadap Prestasi Belajar Mata Pelajaran Ekonomi pada siswa kelas XI IPS SMA Negeri 1 Lasem Jawa Tengah tahun pelajaran 2011/2012". Jurnal Pendidikan Insan Mandiri.

Sugiyono. (2011). Metode Penelitian Kuantitatif, Kualitatif dan R\&D. Bandung: Afabeta.

Sofan Amri (2011). "Strategi Pembelajaran Sekolah Terpadu". Jakarta : PT Pustaka

Suyanto dan Asep Jihad, (2013). “Menjadi Guru Profesional, Strategi Meningkatkan Kualifikasi dan Kualitas Guru di Era Global". Jakarta : Esensi Elangga Group.

Sumanto. (2014). Teori dan Aplikasi Metode Penelitian. Yogyakarta: CAPS (Center of Akademic Publishing Service).

Lickona, Thomas. (2009)." Mendidik untuk Karakter, Bagaimana Sekolah Kita Dapat Mengajarkan Rasa Hormat dan Tanggung Jawab". Jakarta : Esensi Elangga Group.

Wahyudi, (2012). "Manajemen Profesionalisme Guru Strategi Praktis Mewujudkan Citra Guru Profesional". Jakarta : Prestasi Jakarta. 